\title{
Rapidithrix thailandica gen. nov., sp. nov., a marine gliding bacterium isolated from samples collected from the Andaman sea, along the southern coastline of Thailand
}

Correspondence Pornpoj Srisukchayakul pornpoj@tistr.or.th

\author{
Pornpoj Srisukchayakul, ${ }^{1}$ Chatrudee Suwanachart, ${ }^{1}$ Yutthapong Sangnoi, ${ }^{2}$ \\ Akkharawit Kanjana-Opas, ${ }^{2}$ Shoichi Hosoya, ${ }^{3}$ Akira Yokota $^{3}$ \\ and Vullapa Arunpairojana ${ }^{1}$ \\ ${ }^{1}$ Thailand Institute of Scientific and Technological Research (TISTR), 35 Moo 3, Technopolis, \\ Khlong 5, Khlong Luang, Pathum Thani 12120, Thailand \\ ${ }^{2}$ Department of Industrial Biotechnology, Faculty of Agro-Industry, Prince of Songkla University, \\ Hat Yai 90112, Thailand \\ ${ }^{3}$ Institute of Molecular and Cellular Biosciences, The University of Tokyo, Yayoi 1-1-1, \\ Bunkyu-ku, Tokyo 113-0032, Japan
}

Gliding bacteria belonging to the CytophagaFlavobacterium-Bacteroides (CFB) complex have been poorly investigated in terms of their phylogeny, despite the fact that they are one of the dominant bacterial groups in the marine habitat (Pinhassi et al., 1997). The taxonomic position of the CFB complex remains unclear (Shah \& Collins, 1988; Bernardet et al., 1996; Suzuki et al., 2001; Nakagawa et al., 2002). However, this complex has recently been classified as the phylum Bacteroidetes (Ludwig \& Klenk, 2001). Reclassifications and emended descriptions have since been applied to bacteria belonging to this phylum. New genera and novel species of bacteria from marine coastal ecosystems have been found and described as a result of polyphasic taxonomic studies.

Abbreviation: CFB, Cytophaga-Flavobacterium-Bacteroides.

The GenBank/EMBL/DDBJ accession numbers for the 16S rRNA gene sequences of strains TISTR 1736, TISTR 1741 and TISTR $1750^{\top}$ are AB284517, AB265183 and AB265192, respectively.
The family 'Flammeovirgaceae', phylum Bacteroidetes, consists of five genera: Flammeovirga, Flexithrix, Persicobacter, Perexilibacter and Thermonema. The genus Flammeovirga now has four species, Flammeovirga kamogawensis (Hosoya \& Yokota, 2007) and Flammeovirga aprica, Flammeovirga arenaria and Flammeovirga yaeyamensis (Nakagawa et al., 1997), the genus Flexithrix comprises one species, Flexithrix dorotheae (Lewin, 1970), the genus Persicobacter comprises one species, Persicobacter diffluens (Nakagawa et al., 1997), and the genus Thermonema comprises two species, Thermonema lapsum and Thermonema rossianum (Hudson et al., 1989).

The aim of the present study was to establish the taxonomic position of gliding bacteria recovered from the Andaman Sea along the southern coastline of Thailand.

Strains TISTR 1736, TISTR 1741 and TISTR $1750^{\mathrm{T}}$ were isolated from decayed wood from Phuket Province, seashell material from Trang Province and marine algae from Krabi Province, respectively. The medium used for isolation was 
SAP2 agar (Hosoya et al., 2006). Purification of the isolates was performed by using the Skerman micromanipulation technique as described in Sly \& Arunpairojana (1987). These isolates were cultured and maintained at $25{ }^{\circ} \mathrm{C}$ on SAP2 agar.

For determination of phylogenetic relationships, the $16 \mathrm{~S}$ rRNA gene from the novel strains was amplified via PCR by using 16S rRNA gene universal primers. The PCR products were purified by using a GFX PCR DNA and gel band purification kit (Amersham). Sequencing reactions were performed with the ABI PRISM BigDye Terminator cycle sequencing ready kit (Applied Biosystems). Sequences were edited and assembled in the BioEdit program (Hall, 2004) and were compared with sequences by using the BLAST program within the GenBank database (Altschul et al., 1990). Alignments of the 16S rRNA gene sequences of the novel isolates and phylogenetically related genera were carried out by using the CLUSTAL_X program (version 1.83; Thompson et al., 1997). Nucleotide substitution rates ( $K_{\text {nuc }}$ values; Kimura, 1980) were determined and a distance matrix tree was constructed by using the neighbour-joining method (Saitou \& Nei, 1987). Alignment gaps and unidentified base positions were not taken into consideration in the calculations. The topology of the phylogenetic tree was evaluated by performing a bootstrap analysis with 1000 trials.

Phylogenetic analysis of the $16 \mathrm{~S}$ rRNA gene sequence data revealed that the novel isolates formed a distinct lineage within the phylum Bacteroidetes and belonged to the family 'Flammeovirgaceae' (Fig. 1). The $16 \mathrm{~S}$ rRNA gene sequence of strain TISTR $1750^{\mathrm{T}}$ was identical to that of strains TISTR 1736 and TISTR 1741. For analysis of DNA-DNA relatedness, DNA-DNA hybridization experiments were carried out at $40{ }^{\circ} \mathrm{C}$ and levels were measured fluorometrically by using the method of Ezaki et al. (1989). High levels of DNA-DNA relatedness $(87-100 \%)$ were found between these three strains. A BLAST search with the $16 \mathrm{~S}$ rRNA gene sequence of strain TISTR $1750^{\mathrm{T}}$ in the GenBank database and subsequent phylogenetic analysis based on $16 \mathrm{~S}$ rRNA gene sequences showed that strain TISTR $1750^{\mathrm{T}}$ was most closely related to Flexithrix dorotheae IFO $15987^{\mathrm{T}}$
(91\% similarity). Strain TISTR $1750^{\mathrm{T}}$ showed gene sequence similarity levels of $90-91 \%$ to Persicobacter diffluens NBRC $15940^{\mathrm{T}}$, Flammeovirga arenaria NBRC $15982^{\mathrm{T}}$ and Reichenbachiella agariperforans KMM $3525^{\mathrm{T}}$.

The $\mathrm{G}+\mathrm{C}$ content of the DNA was determined by HPLC as described by Mesbah et al. (1989) whereby DNA was extracted and purified according to the methods of Saitou \& Miura (1963). The DNA G +C contents of the novel strains were in the range $40-43 \mathrm{~mol} \%$.

Respiratory quinones were identified according to the method of Uchino et al. (1998). Quinone fractions were extracted with chloroform/methanol $(2: 1, \mathrm{v} / \mathrm{v})$ from lyophilized cells. The fractions were then separated with TLC developed with hexane/diethyl ether $(85: 15, \mathrm{v} / \mathrm{v})$. Quinones were detected under UV light at $275 \mathrm{~nm}$. The quinone spots were scraped off and quinones were extracted with acetone. After concentration, the quinone samples were analysed by reversed-phase HPLC (Komagata \& Suzuki, 1987). The major respiratory quinone of the novel strains was MK-7.

Cellular fatty acids of the novel strains were analysed as methyl esters by GC according to the instructions of the Microbial Identification System (MIDI, Inc.). Fatty acid methyl esters were prepared from bacterial cell mass which was separated from trypticase soy agar medium supplemented with artificial seawater and incubated at $25{ }^{\circ} \mathrm{C}$ for 3 days. The major cellular fatty acids were $16: 1 \omega 5 c$ (cis-5hexadecenoic acid) and 15:0 (pentadecanoic acid). Additionally, the major hydroxyl fatty acids were $3-\mathrm{OH}$ 17:0 (3-hydroxyheptadecanoic acid), 3-OH 15:0 (3hydroxypentadecanoic acid) and 3-OH 16:0 (3-hydroxyhexadecanoic acid) (Table 1).

The phenotypic characteristics of the isolates were determined as follows. Cell morphology and motility were examined under a phase-contrast microscope. Growth at different temperatures and $\mathrm{pH}$ values was tested on SAP2 agar. Oxidase activity was determined by the oxidation of $1 \%$ tetramethyl-p-phenylenediamine on filter paper.

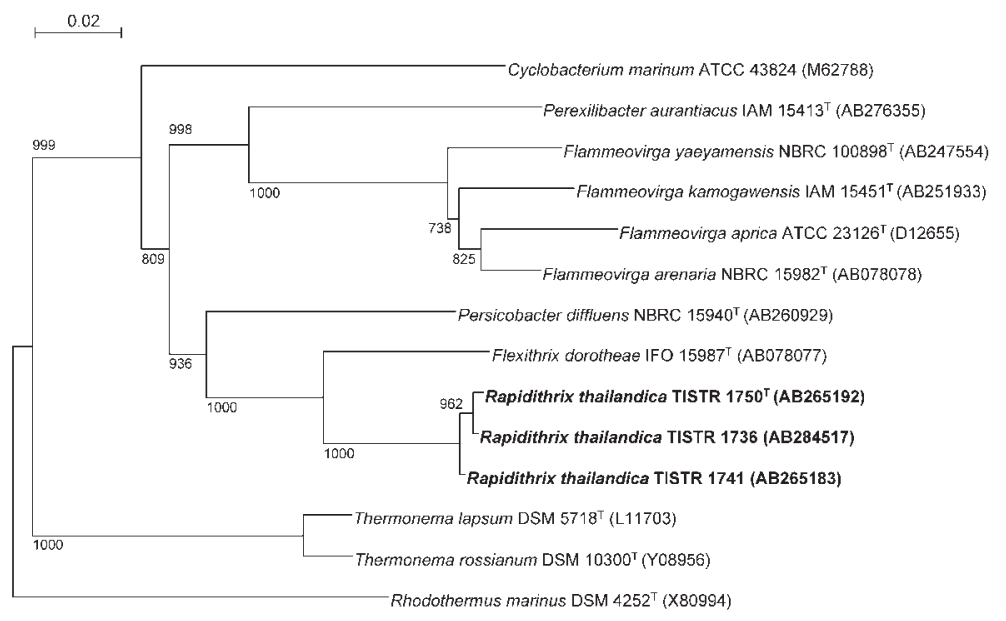

Fig. 1. Neighbour-joining phylogenetic tree showing the positions of strains TISTR 1736, TISTR 1741 and TISTR $1750^{\top}$ and related members of the phylum Bacteroidetes based on 16S rRNA gene sequence analysis. Bootstrap values of $>500$ are given at branch points. Bar, $0.02 K_{\text {nuc }}$. 
Table 1. Cellular fatty acid profile of Rapidithrix thailandica gen. nov., sp. nov.

The first numerals denote the number of carbon atoms in the aliphatic chain and the second numeral, after the colon, denotes the number of double bonds. 2- $\mathrm{OH}$ and 3-OH indicate a hydroxyl group at carbon-2 and carbon-3, respectively; $\omega 5 c, \omega 6 c, \omega 7 c$ and $\omega 9 c$ represent the double bond position from the hydrocarbon end of the carbon chain; $c$, cis-isomer; iso and anteiso indicate an iso- or an anteiso-methyl branched chain. Components comprising $<0.5 \%$ of the total are not shown.

\begin{tabular}{|c|c|}
\hline Fatty acid & Content $(\%)$ \\
\hline $10: 0$ & 1.5 \\
\hline $11: 0$ iso & 2.0 \\
\hline Unknown 13.565 & 1.6 \\
\hline $14: 0$ & 1.2 \\
\hline $15: 0$ iso & 6.3 \\
\hline $15: 0$ anteiso & 0.8 \\
\hline $15: 0$ & 0.6 \\
\hline Summed feature $2(3-\mathrm{OH} 14: 0 / 16: 1$ iso I) & 0.8 \\
\hline $16: 0$ iso & 1.0 \\
\hline 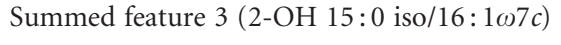 & 1.5 \\
\hline $16: 1 \omega 5 c$ & 44.8 \\
\hline $16: 0$ & 4.0 \\
\hline $3-\mathrm{OH} 15: 0$ iso & 4.3 \\
\hline Summed feature 4 (17:1 anteiso B/i I) & 5.8 \\
\hline $17: 1$ anteiso $\mathrm{A}$ & 0.7 \\
\hline Unknown 16.582 & 0.7 \\
\hline $17: 0$ iso & 1.7 \\
\hline $17: 0$ anteiso & 0.7 \\
\hline $3-\mathrm{OH} 16: 0$ iso & 0.7 \\
\hline $3-\mathrm{OH} 16: 0$ & 3.8 \\
\hline $18: 0$ iso & 0.6 \\
\hline $18: 0$ & 1.4 \\
\hline $3-\mathrm{OH} 17: 0$ iso & 10.8 \\
\hline
\end{tabular}

Catalase activity was tested by bubble formation in a $3 \%$ $\mathrm{H}_{2} \mathrm{O}_{2}$ solution. Hydrolysis of casein, starch (Smibert \& Krieg, 1994), Tweens 20 and 80, and L-tyrosine (Barrow \& Feltham, 1993) were determined by using media in which $0.5 \times$ artificial seawater had been added. Acid production from carbohydrates was studied by using the commercial API $50 \mathrm{CH}$ and API 20 E systems (bioMérieux). Detection of bacterial enzymes was performed by using the commercial API ZYM system (bioMérieux) according to the manufacturer's instructions.

All of the novel strains were Gram-negative, aerobic, nonsporulating, non-fruiting, gliding bacteria. The isolates formed light olive grey colonies. Cells were flexible filaments of $0.7 \times 20-100 \mu \mathrm{m}$ (Fig. 2). The swarm colony spread through the culture plate as a thin film on the agar surface. The typical swarm edge expanded like a sea wave. The phenotypic characteristics of the novel strains are given in the species description below and in Table 2 . The novel strains showed many similar characteristics to those of the genera Flexithrix and Persicobacter, but there were

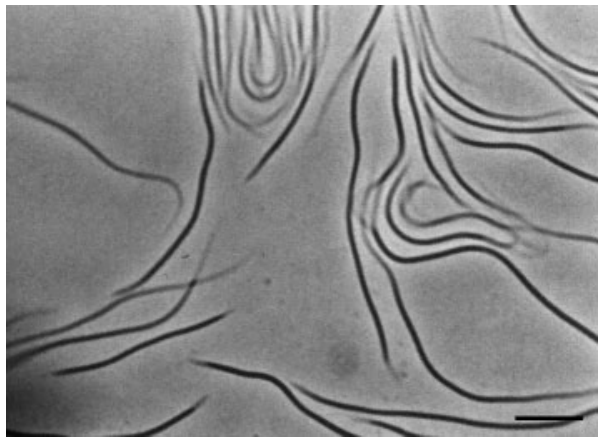

Fig. 2. Phase-contrast micrograph of filaments of strain TISTR $1750^{\top}$. The strain was grown on SAP2 medium at $25^{\circ} \mathrm{C}$ for $48 \mathrm{~h}$. Bar, $10 \mu \mathrm{m}$.

some differences in cell morphology, colony colour, optimum temperature and $\mathrm{pH}$ for growth, oxidase and catalase activity, cystine arylamidase activity, trypsin activity, acid phosphatase activity and DNA G + C content.

On the basis of the results presented here, we propose that the isolates represent a novel species of a new genus within the family 'Flammeovirgaceae', of the phylum Bacteroidetes, for which the name Rapidithrix thailandica gen. nov., sp. nov. is proposed.

\section{Description of Rapidithrix gen. nov.}

Rapidithrix (Ra.pid.i.thrix. L. adj. rapidus rapid; Gr. n. thrix hair; N.L. fem. n. Rapidithrix rapidly moving hair).

Cells are unbranched, flexible filaments, $0.7 \times 20-100 \mu \mathrm{m}$. Motile by gliding. Gram-negative. Resting stages are not known. Chemo-organotrophs. Strict aerobes. Require seawater for growth. The major respiratory quinone is MK-7. The major cellular fatty acids are 16:1 and 15:0. This genus belongs to the family 'Flammeovirgaceae', phylum Bacteroidetes. The type species is Rapidithrix thailandica.

\section{Description of Rapidithrix thailandica sp. nov.}

Rapidithrix thailandica (thai.lan.dic.a. N.L. fem. adj. thailandica pertaining to Thailand, from where the organisms were isolated).

The main characteristics are as those given in the genus description. In addition, the optimal growth temperature is $25-30{ }^{\circ} \mathrm{C}$. The $\mathrm{pH}$ range for growth is $5-10$. Colonies are light olive grey. Peptone and ammonium are useful nitrogen sources for growth. Positive in tests for oxidase, alkaline phosphatase, esterase (C4), esterase lipase (C8), leucine arylamidase, valine arylamidase, cystine arylamidase, trypsin, acid phosphatase, naphthol-AS-BI-phosphohydrolase, $N$-acetyl- $\beta$-glucosaminidase and $\alpha$-fucosidase. Negative in tests for catalase, lipase (C14), $\alpha$-chymotrypsin, $\alpha$-galactosidase, $\beta$-galactosidase, $\beta$-glucuronidase, $\alpha$-glucosidase, $\beta$-glucosidase and $\alpha$-mannosidase. Decomposes 
Table 2. Comparative characteristics of the genera Rapidithrix gen. nov., Flexithrix and Persicobacter

All genera were positive for oxidase and for utilization of peptone and $\mathrm{NH}_{4}^{+}$as a nitrogen source. +, Positive; -, negative; ND, no data available.

\begin{tabular}{|c|c|c|c|}
\hline Characteristic & Rapidithrix gen. nov. & Flexithrix & Persicobacter \\
\hline Cell morphology & Non-sheathed filaments & Sheathed filaments & Long rods \\
\hline Colour of cell mass & Light olive grey & Yellow & Pink to orange \\
\hline DNA G $+C$ content $(\mathrm{mol} \%)$ & $40-43$ & 37.2 & $40-42$ \\
\hline Catalase & - & + & - \\
\hline Cystine arylamidase & + & - & ND \\
\hline Trypsin & + & - & ND \\
\hline Acid phosphatase & + & - & ND \\
\hline Optimum temperature $\left({ }^{\circ} \mathrm{C}\right)$ & $25-30$ & $35-40$ & $25-30$ \\
\hline Optimum pH & $5-10$ & $6.5-8$ & $7-9$ \\
\hline \multicolumn{4}{|l|}{ Cellular fatty acids: } \\
\hline Non-polar & $16: 1 \omega 5 c ; 15: 0$ iso & $16: 1 \omega 5 c ; 15: 0$ iso & $17: 1$ iso; $16: 0 ; 18: 1$ iso \\
\hline $3-\mathrm{OH}$ & $\begin{array}{c}3-\mathrm{OH} 17: 0 \text { iso; } 3-\mathrm{OH} 15: 0 \text { iso; } \\
3-\mathrm{OH} 16: 0\end{array}$ & $\begin{array}{c}3-\mathrm{OH} 17: 0 \text { iso; } 3-\mathrm{OH} 15: 0 \text { iso; } \\
3-\mathrm{OH} 16: 0\end{array}$ & $3-\mathrm{OH} 17: 0$ iso $^{*}$ \\
\hline $\begin{array}{l}\text { Utilization of } \mathrm{NO}_{3}^{-} \text {as nitrogen } \\
\text { source }\end{array}$ & - & + & $-\dagger$ \\
\hline
\end{tabular}

${ }^{*}$ Data from Naganuma \& Horikoshi (1994).

$\dagger$ Characteristic variable with different strains: the type strain is positive.

starch, gelatin, L-tyrosine, and Tweens 20 and 80. Acid is produced from glycerol, D-arabinose, D-xylose, galactose, glucose, mannose, amygdalin, aesculin, cellobiose, maltose, lactose, melibiose, trehalose, gentiobiose and L-fucose, but not from erythritol, L-arabinose, ribose, L-xylose, adonitol, fructose, sorbose, rhamnose, dulcitol, inositol, mannitol, sorbitol, arbutin, inulin, melezitose, raffinose, xylitol, Dturanose, D-lyxose, D-tagatose, D-fucose, D-arabitol, Larabitol or gluconate. The DNA $\mathrm{G}+\mathrm{C}$ content is in the range $40-43 \mathrm{~mol} \%$. The DNA G $+\mathrm{C}$ content of the type strain is $40 \mathrm{~mol} \%$.

The type strain, TISTR $1750^{\mathrm{T}}\left(=\mathrm{IAM} 15448^{\mathrm{T}}\right.$ ), was isolated from marine algae from the Andaman Sea, Krabi Province, Thailand. Strains TISTR 1736 (isolated from decayed wood from the Andaman Sea, Phuket Province, Thailand) and TISTR 1741 (isolated from seashell material from the Andaman Sea, Trang Province, Thailand) are reference strains.

\section{References}

Altschul, S. F., Gish, W., Miller, W., Myers, E. W. \& Lipman, D. J. (1990). Basic local alignment search tool. J Mol Biol 215, 403-410.

Barrow, G. I. \& Feltham, R. K. A. (1993). Cowan and Steel's Manual for the Identification of Medical Bacteria, 3rd edn. Cambridge: Cambridge University Press.

Bernardet, J.-F., Segers, P., Vancanneyt, M., Berthe, F., Kersters, K. \& Vandamme, P. (1996). Cutting a Gordian knot: emended classification and description of the genus Flavobacterium, emended description of the family Flavobacteriaceae, and proposal of Flavobacterium hydatis nom. nov. (basonym, Cytophaga aquatilis Strohl and Tait 1978). Int J Syst Bacteriol 46, 128-148.
Ezaki, T., Hashimoto, Y. \& Yabuuchi, E. (1989). Fluorometric deoxyribonucleic acid-deoxyribonucleic acid hybridization in microdilution wells as an alternative to membrane filter hybridization in which radioisotopes are used to determine genetic relatedness among bacterial strains. Int J Syst Bacteriol 39, 224-229.

Hall, T. (2004). BioEdit. Biological sequence alignment editor for win95/98/NT/2K/XP. http://www.mbio.ncsu.edu/BioEdit/bioedit. html

Hosoya, S. \& Yokota, A. (2007). Flammeovirga kamogawensis sp. nov., isolated from coastal seawater in Japan. Int J Syst Evol Microbiol 57, 1327-1330.

Hosoya, S., Arunpairojana, V., Suwannachart, C., Kanjana-Opas, A. \& Yokota, A. (2006). Aureispira marina gen. nov., sp. nov., a gliding, arachidonic acid-containing bacterium isolated from the southern coastline of Thailand. Int J Syst Evol Microbiol 56, 2931-2935.

Hudson, J. A., Schofield, K. M., Morgan, H. W. \& Daniel, R. M. (1989). Thermonema lapsum gen. nov., sp. nov., a thermophilic gliding bacterium. Int J Syst Bacteriol 39, 485-487.

Kimura, M. (1980). A simple method for estimating evolutionary rates of base substitutions through comparative studies of nucleotide sequences. J Mol Evol 16, 111-120.

Komagata, K. \& Suzuki, K. (1987). Lipid and cell-wall analysis in bacterial systematics. Methods Microbiol 19, 161-207.

Lewin, R. A. (1970). Flexithrix dorotheae gen. et sp. nov. (Flexibacterales); and suggestions for reclassifying sheathed bacteria. Can J Microbiol 16, 511-515.

Ludwig, W. \& Klenk, H.-P. (2001). Overview: a phylogenetic backbone and taxonomic framework for prokaryotic systematics. In Bergey's Manual of Systematic Bacteriology, 2nd edn, vol. 1, pp. 49-65. Edited by D. R. Boone, R. W. Castenholz \& G. M. Garrity. New York: Springer.

Mesbah, M., Premachandran, U. \& Whitman, W. B. (1989). Precise measurement of the $\mathrm{G}+\mathrm{C}$ content of deoxyribonucleic acid by high-performance liquid chromatography. Int J Syst Bacteriol 39, 159-167. 
Naganuma, T. \& Horikoshi, K. (1994). Cellular fatty acids of marine agarolytic gliding bacteria. Syst Appl Microbiol 17, 125-127.

Nakagawa, Y., Hamana, K., Sakane, T. \& Yamasato, K. (1997). Reclassification of Cytophaga aprica (Lewin 1969) Reichenbach 1989 in Flammeovirga gen. nov. as Flammeovirga aprica comb. nov. and of Cytophaga diffluens (ex Stanier 1940; emend. Lewin 1969) Reichenbach 1989 in Persicobacter gen. nov. as Persicobacter diffluens comb. nov. Int J Syst Bacteriol 47, 220-223.

Nakagawa, Y., Sakane, T., Suzuki, M. \& Hatano, K. (2002). Phylogenetic structure of the genera Flexibacter, Flexithrix and Microscilla deduced from $16 \mathrm{~S}$ rRNA sequence analysis. J Gen Appl Microbiol 48, 155-165.

Pinhassi, J., Zweifel, U. L. \& Hagström, Å. (1997). Dominant marine bacterioplankton species found among colony-forming bacteria. Appl Environ Microbiol 63, 3359-3366.

Saitou, N. \& Nei, M. (1987). The neighbor-joining method: a new method for reconstructing phylogenetic trees. Mol Biol Evol 4, 406-425.

Saitou, H. \& Miura, K. I. (1963). Preparation of transforming deoxyribonucleic acid by phenol treatment. Biochim Biophys Acta 72, 619-629.

Shah, H. N. \& Collins, M. D. (1988). Proposal for reclassification of Bacteroides asaccharolyticus, Bacteroides gingivalis, and Bacteroides endodontalis in new genus, Porphyromonas. Int J Syst Bacteriol 38, $128-131$.
Sly, L. I. \& Arunpairojana, V. (1987). Isolation of manganese-oxidizing Pedomicrobium cultures from water by micromanipulation. J Microbiol Methods 6, 177-182.

Smibert, R. M. \& Krieg, N. R. (1994). Phenotypic characterization. In Manual of Methods for General and Molecular Bacteriology, pp. 607654. Edited by P. Gerhardt. Washington, DC: American Society for Microbiology.

Suzuki, M., Nakagawa, Y., Harayama, S. \& Yamamoto, S. (2001). Phylogenetic analysis and taxonomic study of marine Cytophaga-like bacteria: proposal for Tenacibaculum gen. nov. with Tenacibaculum maritimum comb. nov. with Tenacibaculum ovolyticum comb. nov., and description of Tenacibaculum mesophilum sp. nov. and Tenacibaculum amylolyticum sp. nov. Int J Syst Evol Microbiol 51, 1639-1652.

Thompson, J. D., Gibson, T. J., Plewniak, F., Jeanmougin, F. \& Higgins, D. G. (1997). The CLUSTAL_X windows interface: flexible strategies for multiple sequence alignment aided by quality analysis tools. Nucleic Acids Res 25, 4876-4882.

Uchino, Y., Hirata, A., Yokota, A. \& Sugiyama, J. (1998). Reclassification of marine Agrobacterium species: proposals of Stappia stellulata gen. nov., comb. nov., Stappia aggregata sp. nov., nom. rev., Ruegeria atlantica gen. nov., comb. nov., Ruegeria gelatinovora comb. nov., Ruegeria algicola comb. nov., and Ahrensia kieliense gen. nov., sp. nov., nom. rev. J Gen Appl Microbiol 44, 201-210. 